\title{
NARRATIVE SPACE AND TIME IN THE CINEMATIC ADAPTATION OF WALKER'S THE COLOR PURPLE
}

\section{Soha Raafat}

The Color Purple (1982) is a Pulitzer Prize-winning novel written by the feminist, contemporary African American writer Alice Walker. The novel is written in epistolary narrative form mainly from the point of view of the "black, poor and ugly" protagonist, Celie. Most of the letters especially those at the beginning of the novel are addressed to God because as Celie's sister Nettie says to Celie,

I remember one time you said your life made you feel so ashamed you couldn't even talk about it to God, you had to write it, bad as you thought your writing was. Well, now I know what you meant. And whether God will read letters or no, I know you will go on writing them. (110)

Three years later, after the publication of the novel, a Steven Speilberg film treatment of the novel was produced under the same title, 'The Color Purple: Like the novel, the film won several awards. Directors Guild of America Award 1985: Best Director (Speilberg); Golden Globe Awards 1986: Best Actress Drama (Whoopi Goldberg); National Board Review Awards 1985: Best Actress (Goldberg).

John Eliis defines the cinematic production as follows:

.... a photographic medium instantly poses its images and sounds as recorded phenomenon, whose construction occurred in another time and another place. Yet though the figures, objects and places represented ase absen from which the viewing takes place, they are also astoundingly present. The regime of cinematography presents an image which can claim a far higher fidelity and level of complication. (Ellis 38) 
Sinilar to fiction. the narratıve discourse of any lilm can be read in a variety of dilferent wass.

the crilicism of film is an important activity that is engaged in a constant, never-ending process of reevaluating human aims and purposes as they are observed and represented in cinema. (Bywater and Sobchack xiv)

In both the Color Purple and its cinematic adaptation narrative contents, structure and technques can be interpreted within the context of reminism and feminist theories.

Alice Walker's The Color Purple is an example of a woman's novel. This means not just that it was written by a woman. but it carties on an identified tradition of women's writing, in terms of narrative strategies, themes addressed, and voice. (Lavender 1)

As much as the novel can be read within the framework of feminism. its cinematic adaptation is equally presented from a feminist perspective. According to feminist cinemaluc theories.

The aim of the feminist critic is to uncover the hidden structuring devices.... whereby the male maintains dominance and reduces the female to a passive position. (Bywater and Sobchack 183)

Accordingly, the focal points in both works of art are mainly personal relationships; male/female relations and female/female relations within the boundaries of the patriarchal black community during the first half of the twentieth century. Moreover, in both the novel and the film public issues of slavery, racism and, in a larger context, post colonialism are dealt with. However, public issues are tackled extensively in the novel and fragmented in the film. The critic George Stade. for example *. . points to a tension between personal and public issues in the text." (qtd in Selzer 1) 
In the novel, all personal and public issues are integrated together. In the cinematic adaptation, however, more emphasis and most of filmic narration is devoted to the presentation of Celie's fights for her self-esteem and the transformation of her character from a passive 'domestic' position at the beginning of the film to an active, positive and self asserted position by the end of the film. Her self sufferings are mainly because of sexula abuse in childhood by her stepfather and a brutal marriage in a later stage. Her husband tortures her both physically and psychologically to assert his male dominance throughout the gloomy years of their marital life. Her transformation primarily takes place by the support of her sister Nettie in childhood. However, she is forced to be separated from Nettie at one point in their life by the oppressive husband. She is then guided by a free-spirited singer, Shug Avery, who also acts as the link between Celie and Mr. Albert, the husband. Before knowing Celie, Shug has been Mister's lover. Later, she gets involved with Celie in a lesbian relationship which fulfills Celie's physical and spiritual desires. Thus, she restores her whole being by the end. Shug also helps Celin to find her sister's letters hidden by the husband which equally help in the development of Celie's character.

The nartative story time and space in the novel is different from that in the film. In the novel narrative story time and space is divided between personal and public issues including a greater number of events and a wider circle of characters. In the film however, personal relations occupy most of the narrative time and space. In this context, Chatman differentiates between story time and story space saying that:

Story space contains existents, as story time contains events. Events are not spatial, though the occur in space, it is the entities that perform or are affected by them that are spatial. (Chatman 96)

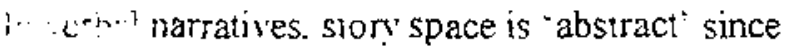

Stor space is roubly removed from the reader. there is not icon or analogy provided by photographed images on screen. Existents and their space. if 'seen' at all are seen in the imagination. Iransformed from words 
into mental projections. There is no "standard sision" of existents as they are in movies. (Chatman 101 )

In The Color Purple, the spatial verbai narrative is of two kinds: oblique descriptions which exist nearly nowhere in spite of the movement of the action treely in time or cinematic descriptions of the actions which draw specific spatial images in the mind of the reader. The latter kind. however, remains equally abstract' as it is all imagined by the reader. (see Chatman 1063)

The cinematic image, however, gives the viewer 'titeral' story space in which cerlain objects, figures, dimensions, illumination, sound effects etc.

are similar to those in real life (see Chatman 101 ). The cinematic story space can be divided into, the 'explicit' story space in which shots are seen on screen or 'implied' story space which is everything implied through the action of the film In general, both verbal scenes presented in a cinematic way or actual cinematic shots in films represent

focus of spatial attention. It is the framed area to which implied audience's attention is directed by the discourse, that portion of the total story space that is 'rernarked' or closed in upon, according to the requirements of the medium, through a narrator or through the camera eye - literally, as in film. or figuratively, as in verbail narratives. (Chatman 102)

The aim of this paper is to investigate narrative time and space in the novel The Color Purple and its cinematic adaptation. Within the frameivork of feminism, both works of art tackle personal and public issues of the African-American community in Georgia during the first half of the twentieth century, 1909-1947. Personal issues are mainly divided into female/ male relations and female female reiations in a black patriarchal society. Public issues basically pivot around problems of slavery and racism in America which are connected with colonialism in Africa.

In the novel, time and space discourse is devoted to the presentation of public issues beside personal issues. Both are carefully interwoven together 
to form a unified time and space narrative. Throughout the verbal narative of the novel both personal and public issues respond to each other in time and space especially in the part of the novel in which Celie, the protagonist transcends her "domestic" passive position, at the beginning of the novel, and starts her struggles in order to grasp the 'universal' position of her sister, Nettie. Therefore, the story time of the novel inciudes a larger number of events in which a larger number of characters are involved.

In the film, however, personal issues are given the larger span of time and space to the extent that public issues are presented as toned down and fragmented. In the filmic narrative the response is presented on a personal level. The harmony takes place within the personal female/ female relations. Personal issues are pictured in the form of parallel shots in which different female characters are involved. Female characters are placed within similar spatial shots but distant temporal ones. Thus a pattern of repetition of spatial images used in different times and including different characters characterize the filmic namative of 'The Color Purple'. These patterns clarify the harmony among female characters and emphasize the unity of their unified feminist identity. Moreover, unified female identities are presented in juxtaposed female/ male images. These juxtapositions take the form of interruptions. Public issues in the cinema are presented as fragmented cinematic metaphors used only to refer to Celie's 'domestic' position in contrast with the spatial 'universal' issues outside her community. The harmony then takes place among female characters in sisterhood relationship between Celie and Nettie in childhood, then in Celie and Shug Avery's love relationship in both childhood and adulthood and finally between the three of them when Celie finds Nettie's letters by the help of Shug. At one point in the novel, parallelism takes place among the three female characters. Thus many characters which exist in the novel are omitted in the cinematic adaptation. Moreover, many events especialiy those related to public issues in the novel do not exist in the film.

Furthermore, there will be an attempl to clarify the difference between wo different types of verbal narrative techniques used in the novel The chlor Purplc, i.e. oblique descriptions and "cinematic" way of presentation. The former move freely in the story time and the story space of the novel. in a few lines. there might be a rendering of a number of events that take 


\section{Soha Raajat}

place along a long temporal time and at different places. However. 'oblique descriptions are known 10 'delimit' the story space of events since ther might exist literally now here".

In verbal story space described in a cinematic way, the reader depends on verbal quatifiers or comparisons with objects of standardized parameters or implied images which can produced certain effects, or the eye of the narrator which projects a certain sense of time and space. These verbal narratives are transformed into specific images of specific dimensions. characters, objects. positions, back ground scenery etc. . . Still, both types whether "oblique" descriptions or "cinematic" descriptions remain abstract and do not induce "standard vision".

In the cinematic narrative, however, elements of space and time are -literal". They do not move as freely as in 'oblique verbal descriptions in the novel. Unike verbal narratives, the film narrative depends on 'explicit' images through the functioning of the camera's lens, the position of characters and objects, degree of reflected illumination, colours, the clarity of optical resolution, sound effects and songs, cinematic metaphors among other cinematic tools to produce complicated shots embedded with many levels of meanings.

Finally, the paper deals with the overail circular patterns of time and space in both the novel and the film. This circular pattern accords with the feminist perspective seen in both works of art.

To begin with, Edward Branigan defines narrative as follows:

.... more than a mere description of place or time, and more even than events in a logical or causal sequence. .. In a narrative, some person, object, or situation undergoes a particular change and this change is measured by a sequence of attributions which apply to the thing at different times. Narrative is a way of experiencing a group of sentences (or gestures or dance movements etc. . ) which together altribute a beginning, middle, and end to something .... Narrative 
is . . a global interpretation of changing data mensured through sets of relationships. (Branigan 4)

The Color Purple is a double structured novel as it deals as above mentioned with personal and public issues. One of the advantages of a double structured novel is that

narrative schema may actually operate more efficiently with . . . causal chains. Intertwining stories provide . . . more ways to imagine causal connections and more opportunities for the overall story to advance. (Branigan 30)

On the personal level, two narrators are involved in the narration of the novel, Celie and Nettie. The reader is, therefore, bound to differentiate between two epistolary narrative styles in each one's letters. The narrative discourse in Celie's letters remains limited to descriptions and events that take place in her black community. Thus, her 'domestic' position is vividly perceived. She never transcends this 'domestic' boundaries throughout the different stages of her self development till the end of the novel. Nettie's letters, however, gradually break up all boundaries of time and space. She acquires a "universal position' as she describes universal issues outside her black community. She deals with stories about missionaries from all places, New York and England. She goes beyond that as she narrates stories about the Olinka people of Africa. Eliott Butler-Evans confirms that

Celie, who remains bound by the time and space of her community, does not alter her language even after coming to a heightened awareness of her situation Nettie who travels abroad and experiences adventure time requires a different language. Both characters, however. remain grounded in their privale relationship. (Butler-Evans 165)

Accordingly; Celie's reaction of fear and wonder as soon as she sees the stamps on Nettie's first letter which belong to different parts of the 
world. the "universal" just charifies her personal lack of awareness of other sparial areas. Linda Selyer argues that

Reveating Celie's ignorance of even the most rudimentary outlines of the larger world ... defines the "domestic site she occupies as the novel's main narrator. In particular. the difficulty Calie has interpreting this envelop underscores her tendency to understand events in terms of personal consequences rather than political categories. (Selzer 1)

On the personal level, therefore, the narrative space and time is only 'domestic' at the beginning of the novel. however, gradually and smoothy Nettie's letters tum it into "universal" in contrast with Celie"s 'domestic' narrative.

Thematically and structurally, in The Color Purple. the story space and time of boch personal and public issues respond to each other. Thus. the personal and the public provide a unified sense of time and space. To illustrate, in one of Nertie's letters sent to Celie from Africa she tells her about an incident that took place betore Nettie's trip to Alrica. i.e. back home. Nettie comments on the racial problem of Sotia Harpo's wife. Harpo is the oldest son of Celie $s$ husband. Albert. In generai. Solia is pictured as a self determined woman who strongly and actively refuses the oppressive laws of parriarchy. Therefore, she devides to leave Harpo s house as soon as he starts using his own powers as a man over her. When she leaves her husband's house, she falls in the hands of whice people who force her to work as the maid of the mayor's wife. She becomes, therefore. doubly oppressed as a result of being black and of being a woman. Therefore, Nettie's letter unifies the personal issues of women with public issues of racial discrimination as she says.

1 don't know if you have seen the mayor's wite. She looks like a wet cat. And there was her mand looking like the very iast person in the world you d expected to see waiting on anybody ... . It was the strangest thing, Celie! One minute I was saying howdy to a living 
woman. The next nothing lising was there. Only its shape. . . . . In the moming I started asking questions about Africa. Well. I read and I read until I thought my eves would fail out. I read where the Africans sold us How we carne to America in ships. How we were made to work. I hadn't realized I was so ignorant. Celie. (1 1)

In the previous passage spatial and temporal narrative of both the personal issue, Sofia's self-asserted womanhood and the public issue of racial discrimination which defeats her self assertion are presented together. Moreover, both are connected to the 'universal' problem of slavery which goes back in time to origins of African Americans, to form the unified time of the verbal narrative of the novei. Generally, throughout the novel free movements from the personal to the public issues prove the unity of both. Moreover, there is also a unity between past time "slavery and present time 'racism'. Spatial distances are also unified.

To keep track of this effect, the novel includes a wider range of settings which are all considered major spatial settings on the personal and public levels. On the personal level, Celie the protagonist is first visualized in her parent's house where she experiences all pains of oppression, sexual abuse by her step-father and phvsical pains of household chores. She then moves to her husband's house where she becomes equally abused physically and psychologically by the husband. After the development of her character, she travels to Memphis with Shug at Shug's house. Finally, she goes back to her parents' house as she becomes its owner after the death of the stepfather.

On the public level, when Nettie starts sending letters to Celie, more settings are employed in the spatial narrative of the novel. Scenes are presented in Africa, New York, England or seafaring trips. However, all are connected to the black community and therefore, connect to the personal.

nover, the novel has a greater number of characters which comuribute to the extension of temporal events. For example, Sofia's sisters clearly tay vital roles of support for Sofia. The two missionaries, Samuel 
and Corrine are involved in a clear way in Nettie s life. Events are equally extended. For instance, al one point after the temporary separation between Celie and Shug, Shug falls in love with a young boy, Germaine. Neither the event nor the character appears in the film. Omissions of cinematic incidents which exist in the novel are numerous. Sofia's life in prison, the raping of Mary Agnes, Harpo's girl friend as results of racial discrimination are omitted. Moreover, all details about the parriarchal societies" norms which go back to African roots are absent in the movie.

In the cinematic adaptation, the unity of time occurs within personal issues only. The unity of cinematic narrative time is apparent in the continuous harmony that takes place among female characters. Personal issues are pictured in the form of repeated shots which are parallel to each other. In other words, the viewer sees certain shots and senses repetition of spatial scenes in which different female characters are involved. To clarify, within sisterhood relations, Nettie provides Celie with love and support urging her 10 get over her passive role. Her support is visualized when Nettie physically exists in the same place with Celie on one hand and in her educating letters sent from abroad on the other hand. Love and support becomes Shug's role in Celie's life after the physical departure of Nettie. Parallelism is not only presented in repeated images. but also it is presented through cinematic lechniques. How'ever. during the extended presentation of patterns of parallelism, intertuptions of the harmony are introduced in other patterns of male/ female relations. John Ellis confirms that, "It is a dangerous undertaking to generalize about narrative procedures, but it is necessary, especially in the area of cinema." (Ellis 62)

To provide concrete examples of the above, some spatial scenes have 10 be described. In the opening scene of the firm. Celie and Nettie are risualized as two young girls playing in a field full of purple flowers. The purple flowers are extremely high to the extent that only the 1wo heads of the two girls beside very small parts of their bodies are seen behind the high stalks of the llowers. Both of them are wearing hats: Nettie's hat is red (a reminist colour) and Celie's hat is black (a gloomy colour). The sharp focus of the camera however, remains on the purple nowers as the children are presented behind them or in the background of the cinematic scene. Nettie runs faster. She is always ahead of Celie. Nettie, however. waits for Celie 
to reach her. She sometimes runs back to hold her sister's hands. They sing together a girl's song, clapping their hands together. The children's song forms a partern of repetition as it becomes a cinematic metaphor for the hamony of their sisterhood. Thus, they sing it together when they grow up and even at the very end of the film.

In other words, their song, which does not appear in the novel, remains a cinematic metaphor of their unified feminist identity

Me and You us never part

Makee da da

No ocean and no sea

Makee da da

Keep my sister away from me

Makee da da.

Suddenty, their step-father interrupts their games as he comes from a far away piace. In one shot he stands among purple flowers; in the next he is seen on short green grass. He orders them to go back home. When they walk towards the green grass area, leaving behind the purpie flowers, the viewer then realizes that Celie is pregnant. Metaphorically, as the viewer realizes later that she has been sexually abused by the step-father, her oppression is what makes her slower than her sister, Nettie.

In adulthood, the same spatial scene is repeated. The scene takes place after the development of Celie's character. However, this time, Celie and, Shug are the two female characters seen in the fieid of purple flowers. Again, purple flowers are high and enclose the bodies of the two characters. Celie's comment adds to the pattern of repetition as she says, "The more things change, the more they stay the same." In the shot, the two walk among the purple flowers freely. Still, Shug walks ahead of Celie as she teaches her a lesson about God. In other words, Celie is still receiving the education needed for her self development. In this scene, she is taught that God is not male or female, but that God is everything that one should admite. 
For Celie. Shug. Iemporarily replaces Nettie who is thrown out of Celie's life by the oppression of the husband. The girl's song referred to in the above inentioned stot has an equivalent one in Celie and Shug s love relationship. Once more the song is about sisterhood and its title is "Miss Celie's Blucs'. Its words are as follows:

Sister you' $\mathrm{ye}$ been on my mind.

Sister we re two of a kind.

So, sister, I'm keeping my eves on you.

I bet you think I don't know nothing

But singing the blues

Oh sister have I got news for you

I'm something

I hope vou think you' re something too.

Again the song is repeated several times in different spatial and temporal shots in the film.

The unity of the three female characters, though apparent in the novel, becomes more easily visualized in the cinema. It is perceived in the scene in which Celie and Shug are involved together in reading Netties first letter. The scene gains importance because of some factors. First, before the existence of this scene Celie has been isolated in her 'domestic' position. After the appearance of the letter, Nettie provides educational guidance which makes Celie aware of other spatial positions outside her own community. Therefore, she transcends her 'domestic' spatial position and her limited view of life to the wider vision of the "universal'. Second. because of the metaphoric projection in the cinerna the three female characters, Celie. Shug and Nettie are connected together in a common experience. Third. the reading of the first letter is the beginning of a tong process of reading other letters that have been hidden by' the husband. Each letter provides Celie with new concepts. Thus it becomes a repealed action in the cinematic narralive.

The scene takes place in an almost bare room except for a bed on which both Shug and Celie are sitting. opposite each other. The room is slightly. darkened. The only source of illumination is a strong beam of natural 
sunlight which flashes between Shug and Celie. When Shug gives Celie Nettie's letter, Celie drops it as if she is afraid to hold it. However, when she opens it. she reads some lines out loudly. Shug, then, takes her tum to complete reading the following lines. Finally, they both read together the rest of the lester till its end, equaly shedding tears of affection.

In fact, reading letters is a repeated action throughout the film. Taking turns in reading Nettie's letter, Shug and Celie emphasize their unity and parallelism with Nettie even if they do not physically exist together in the same place. The unity of the three female characters together is emphasized in the film more than in the novel. In the novel, the relationship between Celie and Shug is rather separated from the relationship between Celie and Nettie. Generally, the pattern of repetition and parailelism is not used only in metaphoric shots and songs, but it is also used atong spatial and temporal images of female characters who are all regarded as identical objects for the fulfillment of sexual desires of men in patriarchal society.

In adulthood, juxtaposition of images starts during the marital life of Celie and Albert especially after Shug's involvement in Celie's life. Love making scenes between Celie and her husband are juxtaposed with love making scenes between Celie and Shug. While the former reflects maie domirance and repuision, the latter certainly reflects harmony and true love between the two female characters.

The love making scenes between Celie and her husband takes place on their wedding day. The bed room is darkened. When the shot starts, strong clicking sounds are first heard. The focus of the camera moves slowly to show a number of men's belts hanging on the wooden back of the bed. The beits shake with the implied shaking of the husband's body during the act. The husband is off screen but the camera then moves to Celie's face. Here head is bandaged and she seems to be in pain as long as the clicking sounds of the belts are heard. In an interior monologue she reveals that she is ac: 1ully :hirking about her sister, Nettie. She then turns her head to the side of ined and finds Shug's picture placed on a table beside the bed among ather 'elontings of the husband. Her thoughts are transferred to the picture of Shu:. The picture then becomes her source of comfort. 
The love making act between Celie and Shug takes place in a strongly illuminated room. In the room, there is a gramaphone that plays light music. Shug is seen standing aione smoking and drinking in the comer of the room. Celie is supposedly behind a screen changing her clothes. Celie is urging her to come to the room quickly. Celie then appears putting on Shug's red dress. However, it looks funny on her. Still, when Shug sees ber, she starts expressing admiration. She takes her to the mirror to familiarize her with her own female image. Shug then dances with her and talks to her. Celie tells Shug about her painful sexual relationship with the husband. Shug sympathizes with her and they kiss each other. This time a musical sound is heard coming from the shaking of a musical ornament hanging at the back of the bed.

Thus, the gloomy atmosphere of the former scene is juxtaposed with the light romantic atmosphere of the latter scene. All cinematic elements are juxtaposed, the degree of light, the cinematic metaphor and the general feelings of repulsion in the male/ female relation which is contrasted with the fernale/ female tenderness. Generally. as John Eljis says,

The pattern of balancing repetition is an economic one A balance between repetition and novely can be said to characterize a film's relationship to the general cultural knowledges that it assumes of its viewers. A film lakes a lot for granted in what it refers to as well as in the way it is constructed intemally.... It mar take for gramed certan meanings, certan assumpiouss. (Ellis 74)

In relating the personal issue to the public issues in the cinema. Steven Speitberg produces a far less successful connection than that of the novel. in the cinema the connection between the black community or Celie on one hand and Africa on the other hand is rather superficial and fragmeniar. The director is more fascinated by presenting African places than by projecting the ideologs behind the presentation of Africa. In the novel, Walker is concemed with the African bondage whicl connects AfricanAmericans with Africar people. However. Speilberg neglects this historical aspect. The connection thus is confined to the presentation of the two 
places where Nettie's letters, Celie reads a description of what a jungle looks like Looking behind her. the shot presents a large elephant crossing bushes in a jungle. Therefore it becomes a superficial personal spatial transcendence aspect rather than a real temporal and bridgeable historical connection between the present time of the novel and the historical origin of African-Americans in the past. Edward Branigan confirms that.

\begin{abstract}
It is not enough, however, merely to juxtapose two motives ... and hope for the best . . . the narration (here) seeks to limit the scope of metaphors ... . Thus, it would be better to think of narration not as a proposing and abolishing contradictions with varying degrees of explicitness and success. (Branigan 31 )
\end{abstract}

Therefore, as above mentioned, the link between personal and public issues is limited in the movie. Because of its oversimplified implications, it becomes confined only to Celie's personal development and her need to bridge the gulf between herself and her sister.

Another important aspect reiated to the story time and the story place is apparent in the various techniques used in the verbal narrative of the novel and the cinematic narrative of the film. The verbal narrative of The Color Purple is divided into 'oblique' narrative descriptions and cinematic narrative description. Chatman confirms that 'oblique' descriptions 'delimit' story space,

a narrator may delimit story-space whether in direct descriptions, or obliquely, en passant . . . . The narrator may be omnipresent (a power separate from omniscience). Omnipresence is the narrator's capacity to report from vantage points not accessible to inirracters, or to jump from one to another, or to be at u places at once. (Chatman 103)

So: \& mentioned, the main narrator's ornnipresence enables her to jump it $\ldots$. ne phace to another. Therefore, the use of 'oblique' descriptions in iii. : 3 landles the story space and time freely and on a wider scale. 
However. these "oblique' descriptions make the incidents appear to exist almost 'nowhere". Therefore, as they move freely in time the 'delimit' the imagination of the reader in relation to spatial aspects. To clarify, in a short passage in the novel, Celie describes her mother s sickness, her experience of giving birth to her second child, her deprivation of motherhood by the oppressive stepfather saying.

She ast me bout the first one whose it is? I say God's. I don't know other man or what else to say. When I start to hurt and then my' stomach start moving and then that little baby came out ... you could have knock me over with a feather.

Don't nobody come see us.

She got sicker and sicker.

Finally she ast where it is?

I say God took it. He took it while sleeping. Kilt it out there in the woods. Kill this one too: if he can (4)

In the above dialogue, the narrator moves from one scene to the next, this quick movement from one temporal incident to another. delimits the narrative story space as it leaves no chance for the reader's imagination to produce clear spatial images of the temporal events.

In the verbal narrative of the novel cinematic ways for descriptions provide rather specific spatial aspects of the events. Chatman argues that

\footnotetext{
Verbal narratives can also depict movement through story space. even in cinematic ways. . . . the effect is like a "pan' in a film ... Our focus of attention is continuously moved. (Chatman 101)
}

In the novel. cinematic techniques are used in the verbal narrative of the novel. An example of that ype of technique is shown when Alben. the husband comes back home bringing Shug with him. Even before knowing her. Celie has admired and aclually fallen in love with Shug's picture. Therefore. when she realizes that Shug has arrived home suddenly. she becomes worried as she wants Shug to see her in good shape. 
Five days later, $I$ look way off up the road and see the wagon coming back. It got sort of a canopy over it now, made out of old blankets or something. My heart begin to beat like furry, and the first thing 1 try to do is change my dress. But too late for that. By time I git my head and arm out the old dress, I see the wagon pull up in the yard. Plus a new dress won't help none with my notty head and dusty headrag, my old everyday shoes and the way I smell. I don't know what to do, I' $\mathrm{m}$ so beside myself. I stand there in the middle of the kitchen. Mind whirling . . . Celie, I hear Mr. -..- call. Harpo. I stick my head and my arm back in my old dress and wipe the sweat and dirt off my face as best I can. I come to the door. Yessir? I ast, and trip over the broom I was sweeping with when I first notice the wagon. (41)

In the above scene, all cinematic techniques are used to produce an imaginary scene in the mind of the reader. We see this scene from the point of view of the main narrator of the novel, Celie. We visualize things through her eyes. Reading the passage, the reader can imagine Celie in the house sweeping the floor while the wagon comes from an opposite direction towards the house. The quick tempo of the passage can be perceived and her confusion can be easily visualized in 'I try to change my dress. But too late for that." The sense of time is accelerated for the narrator. One moment, she decides to change her dress but then there is not enough time because the wagon is moving closer towards the house. Her physical appearance is visualized by the use of verbal qualifiers in 'notty' head and dustr headras. my old everyday shoes.' The qualifiers present her in her worst condition. Her spatial position is located in "the middle of the kitchen. Later her movement towards her husband as he calis her is seen in 'I come to the door' and 'trip over the broom I was sweeping with."

The cinematic technique used in verbal narration does not move freely. and quichly. from one place to the next as it is the case with "oblique descriptions: They certainly induce certain images in the mind of the 
reader as they draw ligurative visions of specific objects. appearance of characters and their movements, a sense of the space in which the action takes place through the use of the point of view and the verbal qualifiers provided. However, like 'oblique descriptions", "cinematic descriptions" are abstract as they do not provide 'standard vision' of images.

In the cinematic adaptation of The Color Purple. 'literal' images are sisualized. All cinematic images reflect the director's own vision of the literary text.

The cinematic regime of visual and aural representation is spectacular in its effects, because its effects are sure to be noticed. It is also concentrated, by means of ellipsis in editing or of elaborate staging for spectacular long takes. It produces ambiguity in the image more than one area of attention. All of this takes place within a particular regime of representation: the photographic. (Ellis 57)

In the cinematic narration of The Color Purple, the director sometimes elaborates fictional metaphors or even transforms verbal descriptions into highly complicated spatial and temporal shots. His tools are all visual and aural tools. They are optical angles of the camera, repeated cinematic metaphors, different degrees of illumination, colours, contrastive ordering and disordering of time sequence, break up of the causal chain of events, sound effects and songs among others.

Throughout female characters are seen as identical objects in the eyes of men within the norms of the patriarchy. Male characters are regarded as superior to women. In the movie, therefore, Albert, Celie's husband is seen in a 'physically' higher position than Celie and Nettie; on horseback or at the top of the porch's stairs. The women in such a shot would be standing in a 'physically' lower position, on the ground or at the bottom of the stairs. $\mathrm{He}$ is on horseback when he goes to Celie, the girl whom he intends to marry. He is also on horseback when he chases Nettie in the woods in order to seduce her. In both shots, Celie and Nettie are seen as 'preys' in front of a hunter. The optical angle of the camera clarifies his superior position. 
This accords with criticism of feminist practices in the cinema which affirms that

The analogy .... is to the general notion in the world outside the theater, that men are "Jookers" at women. They look at women with a sexual gaze, taking pleasure in the physical appearance of the female. usualiy whether the female wants it or not. Thus the look of the camera appears to have the characteristic of the male gaze rather than the female or neutral one. (Bywater and Sobchack 185)

The identical image of both sisters in the eyes of Albert is metaphorically pictured in a shot in which the viewer only sees them as two shadow reflections on the wall. Their facial features cannot be separately recognized. In the same shot, when Nettie plavfully tries to imitate the husband, she jumps out of her shadow into the middle of a circle of light. When she is finished, she jumps back to her previous position and her image becomes an image of a shadow again. The viewer watches this scene through the open door of a room. However, as the camera zooms out, the viewer realizes that the shot is presented from the point of view of Albert who has been watching the two sisters from outside. The time sequence of his implied presence precedes the action that the two giris are involved in. Therefore as Branigan says, the viewer is

$\ldots$ forced to mentally, readjust the order of events
reference point, as a new condition for our seeing . . .
In any event, what is important is that the shots require
the spectator to refigure the temporal scheme.
(Brangan 42 )

Demin slours and extended metaphors are used as cinematic technical devices in the film. Purple and red are used to refer to feminist issues becaust as Jacci Bear says. 
Purple is rosaly. A mysterious color, purple is associated wit both nobility and spirituality . . . Purple has a special. almost sacred place in nature . . . Purple might suggest unique or extremely special but with an air of mystery. (Bear l)

At the beginning of the film. Netle is seen putting on a red hat. Twice in the film, Celie. Nettie and Shug are seen in fields of purple flowers. At the end of the fim when Nettie returns to Celie, she is dressed in a purple and red dress and has shawls of the two colours that fly up in the air like flags.

The extended metaphor of blood as related to Celie's oppressed life is used throughout. This metaphor emphasizes her above discussed image as a prey. In her pareris' house labour blood is seen in the camera's focus in a shot in which she gives birth to her second child. This metaphor is repeated on the wedding day of Celie. Before she steps into her husband's house his son Harpo hits her with a stone that makes her head bleed. She puts her hand on her head and then she prints her blood stained paim on a large stone at the door of the house. In addition, during her life with the husband, he slaps her on the face from time to time and every time he does that, her nose bleeds.

The degree of illumination is a vital techrique used in the film. Light is used to emphasize the power of men as clarified in the above discussed scene about the shadows of the two sisters. Also, in the scene when Ceire is giving birth to a child, the stepfather stands outside the room carrying a lantern. When he steps into the room, the reflection of the light on Nettie s face makes her afraid of what is to come. After the development of Celie's character, light becomes a symbol of harmony as it is seen in the love making act between Celie and Shug as juxtaposed with the dark room where Celie and Albert are making love. Finally, light is used as a symbol of education especially that it is natural light which is used in the shot when Celie reads Nettie's letter.

Last but not least, songs and sound effects contribute to convey required effects to the viewer. The film is embedded with feminist songs accompanying the tender gestures among female characters. The songs are 
repeated several times during the temporal and spatial events of the film. African music with its quick tempo is used to add to the sense of place. Sound effects are also used in the film. For example, when Albert is chasing Nettie in the woods. the only sound heard at that shot is the sound of the brealh of his horse as a symbol of his animalistic desire.

Generally, it is clear that the temporal and spatial aspects of both the novel and its cinematic adaptation are circular rather than linear. in the novel, the circular pattem of the narrative is perceived in the connection of the past and the present times of the novel. This link is echoed in the historical link between Africans and African-Americans. In the film. repetitive patterns in the female/ female relations make the action seen as circular in form. The repetitive patterns are both structural and technical. This accords with feminist theories of literature. Annis Pratt, for example, affirms that, "since women are alienated from time and space, their plots take on cyclical rather than linear form." (Pratt il)

To conclude, both the novel and the film can be regarded as successful works of art though their spatial and temporal narratives are different. Structurally, the novel tackles public issues as much as it tackles personal issues. In the film, Speilberg deals with personal issues oniv. He, therefore. elaborates and omits characters, places and temporal events to create his own vision of Walker's novel.

In his elaborations and omissions, he employs various visual and aural cinematic techniques which are absent in the novel, i.e. the camera's angle and focus, position of characters, metaphors, dominance of colours, light, sound effects, music and songs. Every technique has its function which contributes to highly complicated spatial shots. With a careful cinematic critical examination each technique is vital because of its deep implications. John Ellis affirms that "As the film text is watched at a sitting, usually without interruption, the chain of narrative events can be compressed and complicated at the same time." (Ellis 70)

The main problem with the cinematic adaptation of The Color Purple lies in the director's superficial connection of personal to public issues. However, it remains a manifestation of feminist films which present "the 
Soha Raạlat

way women are portraved by the culture in all forms of images." (Bywater and Sobchock I \&3)

Genet ally. The Color Purple is described as

the biggest mainstream epic by and about AfricanAmericans, all eves were turned toward it. Walker was scrutinized by the press, and every nuance of the story was analyzed. Through it all, only one opinion mattered for Walker. Purple was written for her mother . . . and it pained Walker to know that her mother had never read the book Her mother did see the movie, however, .... and told Walker she couid see some of her life on the screen. (Yvette Walker l) 


\section{WORKS CITED}

\section{Primary Sources:}

Walker, Alice (1982). The Color Purple. Orlando: Harcourt Brace Jovanovich Publishers.

Speilberg, Steven (1985). 'The Color Purpie - Wamer Home

Video'. Wamer Bros. Inc. A Wamer Communications Company.

\section{Secondary Sources:}

A. Books

Braningan, Edward (1992). Narrative Comprehension and Film. New York and London: Routledge.

Bywater, Tim and Thomas Sobchack (1989). Introduction to Film Criticism, Major Critical Approaches to Narrative Film. New York and London: Longman.

Chatman, Seymour (1978 - 1993). Story and Discourse. Narrative Strategy in Fiction and Film. Ithaca and London: Comeil University Press.

Eliott, Butler-Evans (1989). Race, Gender and Desire, Narrative Strategies in the Fiction of Toni Cade Bambara, Toni Morrison and Alice Walker. Philadelphia: Temple University Press.

Ellis, John (1982). Visible Fictions, Cinema: Television: Video. London and Boston: Routledge and Kegan Paul.

Pratt, Annis with Barbara While, Andrea Loewenstein and Mary Wyer (1981). Archetypal Patterns in Women's Fiction: Bloomington: Indiana University Press.

\section{B. Articles, Reviews, and Interviews and Internet}

Bear, Jacci Howard. 'Purple and Lavender Color Symbolism'. 
http://desktonpub.about.com/compute/desktoppub/lib.../blcspurple.h tm?terms=thktcolor + purple. $1-3.4 / 4 / 01$.

Lavender, Catherine. 'Alice Walker, The Color Purple (1982)'.

http:/www librarycsicunny.edu/dept/historv/lavender/purple. html 1 - 4. 4/4/01.

Selzer, Linda. 'Race and domesticity in 'The Color Purple'.

http:/www'sestahspace.con/sistory/writers/walker/race.html $1-6.4 / 4 / 01$.

Templeton, David. 'Difficult Honor, The Same River Twice: Honoring the Difficult by Alice Walker'.

http://www metroactive.com/papers/sonoma/02.15.96/waiker $-9607 . \operatorname{lntml} 1$ - 2. 1/15/01.

Walker, Yvette. 'Walker, haunted by 'Purple', offers apology and footnotes'. hitp://detnews.com/menu/stories/38025.html I 2. $1 / 15 / 22$. 